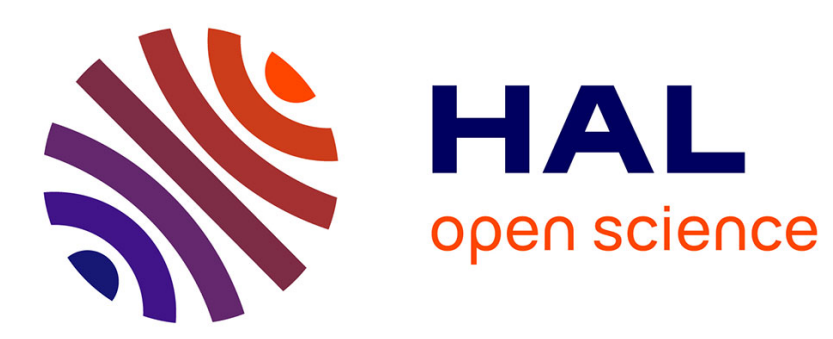

\title{
The demographic and adaptive history of central African hunter-gatherers and farmers
}

\author{
Etienne Patin, Lluis Quintana-Murci
}

\section{To cite this version:}

Etienne Patin, Lluis Quintana-Murci. The demographic and adaptive history of central African hunter-gatherers and farmers. Current Opinion in Genetics and Development, 2018, 53, pp.90-97. 10.1016/j.gde.2018.07.008 . hal-02352848

\section{HAL Id: hal-02352848 \\ https://hal.science/hal-02352848}

Submitted on 12 May 2020

HAL is a multi-disciplinary open access archive for the deposit and dissemination of scientific research documents, whether they are published or not. The documents may come from teaching and research institutions in France or abroad, or from public or private research centers.
L'archive ouverte pluridisciplinaire HAL, est destinée au dépôt et à la diffusion de documents scientifiques de niveau recherche, publiés ou non, émanant des établissements d'enseignement et de recherche français ou étrangers, des laboratoires publics ou privés.

\section{(1)(1) $\$(0)$}

Distributed under a Creative Commons Attribution - NonCommercial - ShareAlikel 4.0 


\section{The demographic and adaptive history of central African hunter-}

\section{2 gatherers and farmers}

3

4 Etienne Patin ${ }^{1,2,3}$ and Lluis Quintana-Murci ${ }^{1,2,3}$

5

$6{ }^{1}$ Unit of Human Evolutionary Genetics, Department of Genomes and Genetics, Institut Pasteur,

775015 Paris, France

$8 \quad{ }^{2}$ Centre National de la Recherche Scientifique (CNRS) UMR2000, 75015 Paris, France

$9{ }^{3}$ Center of Bioinformatics, Biostatistics and Integrative Biology, Institut Pasteur, 75015 Paris,

10 France

11

12

13

14

15

16

17 Correspondence to: epatin@ pasteur.fr or quintana@ pasteur.fr

18

19 


\section{Abstract}

2 Central Africa, a forested region that supports an exceptionally high biodiversity, hosts the

3 world's largest group of hunter-gatherers, who live in close proximity with groups that have

4 adopted agriculture over the past 5,000 years. Our understanding of the prehistory of these

5 populations has been dramatically hampered by the almost total absence of fossil remains in this

6 region, a limitation that has recently been circumvented by population genomics approaches.

7 Different studies have estimated that ancestors of rainforest hunter-gatherers and Bantu-speaking

8 farmers separated more than 60,000 years ago, supporting the occurrence of ancient population

9 structure in Africa since the Late Pleistocene. Conversely, the Holocene in central Africa was

10 characterized by large-scale population migrations associated with the emergence of agriculture,

11 and increased genetic interactions between autochthonous rainforest hunter-gatherers and

12 expanding Bantu-speaking farmers. Genomic scans have detected numerous candidate loci for

13 positive selection in these populations, including convergent adaptation for short stature in

14 groups of rainforest hunter-gatherers and local adaptation to endemic malaria in western and

15 central Africans. Furthermore, there is recent increasing evidence that adaptive variation has been

16 acquired by various African populations through admixture, suggesting a previously

17 unappreciated role of intraspecies gene flow in local adaptation. Ancient and modern DNA

18 studies will greatly broaden, and probably challenge, our view on the past history of central

19 Africa, where introgression from yet uncharacterized archaic hominins and long-term adaptation

20 to distinct ecological niches are suspected. 


\section{Introduction}

2 The central African belt - a vast territory that extends from the Congo Basin in its western part

3 to Lake Victoria in its easternmost part - is mostly covered by dense rainforests and supports

4 one of the highest levels of biodiversity worldwide. This region is key to understand African

5 prehistory, population structure and dynamics as it harbours both the largest living group of

6 active hunter-gatherers, the rainforest hunter-gatherers, as well as Bantu-speaking, agriculturalist

7 communities [1-3]. These two groups differ not only in their subsistence patterns (i.e., broadly,

8 although not exclusively, hunting and gathering versus farming) but also in their lifestyle,

9 ecologies and exposure to environmental pressures [4] and diseases [5]. While most farming

10 communities are sedentary and live in rural or urban areas, rainforest hunter-gatherers

11 traditionally live in huts in the rainforest, moving regularly from one camp to another.

13 African rainforest hunter-gatherers (RHG) - collectively known by the historical and derogatory

14 term "Pygmies" - are broadly subdivided into two groups that reflect their geographic location

15 [6]. Western RHG inhabit the Congo Basin and include multiple populations such as the Baka,

16 Aka, Koya or Bongo, whereas Eastern RHG live close to the Ituri rainforest and Lake Victoria

17 and comprise groups such as the Asua, Sua, Efe or BaTwa. In addition to a forest-dwelling mode

18 of subsistence, Western and Eastern RHG share distinctive cultural and phenotypic traits, such as

19 specific hunting and honey-gathering techniques and a trait known as the "pygmy phenotype",

20 i.e., small adult body size distinctive of certain African, Southeast Asian and South American

21 populations [7]. African RHG, particularly those of the Ituri rainforest, show the lowest average

22 adult stature worldwide, of $<155 \mathrm{~cm}[8]$.

23 
1 Bantu-speaking, agriculturalist populations of central Africa are thought to descend from early

2 farming communities that recently expanded across sub-Saharan Africa [9]. The central African

3 belt is also key in this respect, as it is adjacent to the postulated homeland of Bantu languages,

4 where agriculture possibly emerged 3-5 Ky ago, in the area that corresponds today to Southeast

5 Nigeria and Western Cameroon [3]. The appearance of pottery and polished stone tools within

6 this time frame, together with the shared languages and oral traditions of farmers and hunter-

7 gatherers, indicates an early and extensive history of economic and technological exchanges

8 between the ancestors of these two communities $[1-3,8,10]$. These contacts have been maintained

9 until today; for example, some groups of rainforest hunter-gatherers remain sedentary for some

10 time due to strong socioeconomic dependence on neighbouring farmers.

12 The lacks of archaeological data for central Africa, in particular for the Congo Basin owing to the

13 rapid disintegration of fossil remains in the rainforest's acidic soils, have hampered the

14 understanding of demography and adaptation of populations inhabiting this region. How the

15 increasing availability of genomic data from populations of the region has counteracted this

16 limitation is the goal of this review. We focus on how genomic studies of rainforest hunter-

17 gatherers and farmers have been of paramount importance to infer their past demography -

18 population splits, sizes changes and gene flow - as well as their history of biological adaptation,

19 highlighting the importance of admixture as a possible source of new adaptive variation.

\section{Deep divergence of central African populations in the Late Pleistocene}

22 While the late Pleistocene is thought to have witnessed modern human diversification within

23 Africa [11], the human fossil record of central Africa is exceptionally sparse for this period [12]. 
1 The oldest samples studied have been dated at 20-25 Ky, and suggest that the biological and

2 cultural diversity of central Africa during this period was considerable [13]. However, it is

3 currently unknown if such diversity was a local exception, or a general rule in the diverse

4 ecological regions composing central Africa.

5

6 The study of the genetic diversity of present-day populations represents an alternative, powerful

7 approach to infer past population histories and ecologies. Population genetic studies have shown

8 that present-day RHG and farming populations are characterized by one of the deepest splits in

9 human evolution $[14,15]$. The combined modelling of 16 high-coverage whole genomes supports

10 a separation of the ancestors of RHG and the west African Yoruba $90 \mathrm{Ky}$ (85-92) or $155 \mathrm{Ky}$

11 (139-164) ago, assuming either instantaneous or continuous asymmetric gene flow between the

12 two groups [14]. A similar approach recently applied on 300 exomes of RHG and Bantu-

13 speaking farmers has estimated that their ancestors diverged $135 \mathrm{Ky}$ (57-259) ago [15] (Figure

14 1), assuming the most recent estimations of mutation rate [16] and generation time [17]. Under

15 the same assumptions, the former study supports a population split as old as $300 \mathrm{Ky}$ ago, while

16 previous studies based on independent autosomal regions support a separation $~ 110 \mathrm{Ky}$ ago

$17[18,19]$. Despite discrepancies between estimates, which may be due to imperfections in the

18 models, low sample sizes, or the effects of background selection, they all support ancient

19 structure among the ancestors of rainforest hunter-gatherer and farmer populations, in agreement

20 with the proposed human diversification within Africa during the Late Pleistocene [11].

22 Seminal ancient genomic studies have revealed that Neanderthals contributed $\sim 2 \%$ of the genetic

23 variation of present-day non-Africans [20-22], while Denisovans contributed $\sim 5 \%$ of genetic

24 variation to modern Melanesians [23-25]. Despite the coexistence throughout Africa of diverse 
1 forms of Homo with both archaic and modern traits during the Pleistocene [26], few studies have

2 yet provided robust evidence of archaic introgression in Africa. Reference-free methods have

3 nonetheless identified in RHG genomes hundreds of candidate introgressive loci, which are

4 strongly depleted in genic regions [27-29]. Whether these observations reflect archaic admixture

5 or ancestral structure [30] remains to be determined.

\section{Demographic transitions and admixture during the Holocene}

8 The Holocene in central Africa was characterized by a global warming after the Last Glacial

9 Maximum, and the increase of forested areas followed by short episodes of forest contraction

10 from 4 Ky onward [31,32]. These deforestation events were concomitant with the well-

11 documented expansion of Bantu languages from the modern-day Nigeria-Cameroon border

$12[3,33,34]$. The Bantu expansion is thought as one of the most influential cultural events of

13 African prehistory, as it spread a new, more sedentary lifestyle that ultimately led to the diffusion

14 of agriculture and iron-smelting technology across sub-Saharan Africa. Population genetic

15 studies have revealed that present-day Bantu-speaking populations (BSP) of central, eastern and

16 southern Africa present little differentiation [35-37], supporting their recent separation during the

17 Bantu expansion. Haplotype-based approaches, together with linguistics [34] and archaeoclimate

18 data [9], all support a model in which early BSP first moved southward through the rainforest,

19 before migrating toward eastern and southern Africa [37-39]. Interestingly, the signal of

20 population growth observed in BSP genomes cannot be solely explain by an expansion occurring

$213-5 \mathrm{Ky}$ ago, suggesting that their ancestors were already a demographically successful group

22 prior to agriculture emergence $[40,41]$.

23 
1 As they dispersed throughout central Africa, BSP encountered local RHG populations. Several

2 studies indicate that admixture occurred between the ancestors of these two groups [18,35-37,41-

3 45]. Model-based methods have estimated that gene flow from BSP to RHG was greater than the

4 opposite [14,15] (Figure 1), resulting in high BSP ancestry among some RHG groups [18,41,43-

5 45]. Furthermore, uniparentally-inherited and X-linked markers have revealed that gene flow

6 from BSP to RHG was male-biased $[41,44,46]$. However, asymmetrical male-biased gene flow is

7 not systematically observed across western RHG groups [41,44], suggesting variable

8 intermarriage customs. While modelling approaches based on the site frequency spectrum have

9 estimated a time of admixture as old as $\sim 7 \mathrm{Ky}[14,15]$ (Figure 1), decay of admixture linkage

10 disequilibrium is compatible with admixture occurring mostly during the last millennium [37,41].

11 We anticipate that methodological improvements allowing parameter estimation under both

12 instantaneous and continuous admixture models [47] will help resolving these apparent

13 discrepancies.

\section{Population size changes and the burden of deleterious mutations}

16 Understanding how demographic events such as explosive growth or bottlenecks have affected

17 the ability of populations to purge deleterious variants is crucial for the dissection of the genetic

18 architecture of diseases [48-50]. Fuelled by the availability of population sequencing data, there

19 has been increased interest on whether human populations carry differential burdens of

20 deleterious alleles (i.e. mutational load). Despite some initial controversy, the consensus today is

21 that the demographic events experienced by the majority of human populations have not been

22 long or severe enough to impact, at least to a detectable extent, mutational load under an additive

23 model of dominance, whereas they may impact load under a recessive model [51-53]. 
2 The question of how population size changes affect mutational load is especially relevant in

3 hunter-gatherer history, as their subsistence patterns are expected to be associated with a unique

4 demography $[15,18,19,41]$. Based on exome sequencing data from RHG and BSP from western

5 and eastern central Africa, a recent study has explored, using simulations, the trajectories of

6 mutational load across populations, and examined the model of dominance that is most

7 compatible with the patterns of deleterious variation [15]. Despite the marked population

8 collapses and expansions experienced by RHG and BSP, respectively (Figure 1), both groups

9 exhibit similar load under an additive model. Furthermore, the historically large effective

10 population size of RHG, together with the gene flow received from neighbouring farmers, have

11 counteracted the predicted effect of the recent and strong population decline of RHG on their

12 recessive load.

14 In the absence of knowledge of the average distribution of dominance coefficients across the

15 genome and full consideration of rare variants located in both coding and non-coding regions, the

16 question of the extent of mutational load differences between hunter-gatherers and farmers, and

17 more generally among human populations, remains open.

19 Signatures of local adaptation in rainforest hunter-gatherers and farmers

20 Despite rainforest hunter-gatherers and farmers cohabit along the central African belt, their

21 history of population divergence dates back to $>60 \mathrm{Ky}$ ago $[14,15,18,43]$. Their differences in

22 effective population sizes appear to result from demographic events that predate the first farmers' 
1 expansions 3-5 Ky ago [41], suggesting a long — and probably different — history of biological 2 adaptation.

4 The "pygmy phenotype" [7] appears to have a genetic basis, at least in Africa [45,54,55], and its

5 adaptive nature - proposed to be associated with higher fitness in rainforest environments

6 through thermoregulation, food limitation, improved mobility or earlier reproduction $[7,8,56,57]$

7 - is increasingly supported [58]. Population genetic studies have detected signatures of positive

8 selection targeting a largely non-overlapping set of genes in various RHG groups

$9[14,29,45,55,59-62]$, possibly reflecting false positives. The relevance of some candidate loci is

10 nonetheless supported by functional and epidemiological studies; for example, FLNB and EPHB1

11 present not only robust signatures of positive selection but also variation that affect body size in

12 model organisms or is associated with human height $[14,29,45]$ (Figure 2). That studies of

13 different RHG groups detect different candidate genes for the pygmy phenotype may also reflect

14 convergent adaptation within Africa, as supported by population genetics data [55] and analysis

15 of longitudinal growth rates in western and eastern RHG groups [63].

17 Functional categories of candidate genes evolving adaptively among RHG also involve

18 reproduction, cell signalling, neural development and immune functions [14,29]. Beside all these

19 cases of candidate selective sweeps, signals of polygenic adaptation [64] have been also detected

20 among RHG, related to the pygmy phenotype [55] and immunity-related processes (i.e. antigen

21 binding and pattern recognition receptor activity) [14].

23 Genetic adaptation related to host defence against pathogens has been pervasive among African 24 populations $[65,66]$. The pressure imposed by Plasmodium - the causative agent of malaria - 
1 largely characterises the history of positive selection of sub-Saharan Africans [67], particularly

2 that of western and central African farming communities [36,37]. Highly supported cases of

3 genes that have evolved adaptively in response to malaria include $H B B, D A R C$ ( $A C K R 1$ ), G6PD,

$4 \quad C R 1$ and $C D 36[36,68-74]$ (Figure 2), variation in which confers protection against falciparum

5 or vivax malaria [67]. Other cases of genetic adaptation include APOL1, conferring resistance to

6 Trypanosoma brucei [75], LARGE, implicated in Lassa virus infectivity and immunity [76],

$7 \quad T L R 5$, associated with decreased NF-אB activity [77], as well as several loci putatively involved

8 in adaptation to temperature and osmoregulation [36]. All these studies have collectively

9 broadened our understanding of the ecological pasts of populations of central Africa that differ in

10 their carrying capacities and modes of subsistence.

\section{Admixture as a vehicle of genetic adaptation}

13 Recent studies have highlighted a previously unappreciated role of admixture and gene flow as an

14 important source of adaptive genetic variation, from ancient hominins such as Neanderthals or

15 Denisovans [30,78,79], or between modern human populations $[37,80,81]$.

17 Within Africa, BSP rapidly dispersed in less than $3 \mathrm{Ky}$, and had to adapt to new ecosystems.

18 Recent data has shown that during their dispersals, BSP acquired advantageous genetic variation

19 via admixture with the local populations they encountered [37]. For example, BSP from western

20 central Africa acquired adaptive variants at the $H L A-D$ gene locus through admixture with RHG,

21 and BSP from eastern Africa acquired the lactase persistence trait through gene flow from east

22 African pastoralists [37] (Figure 2). Another study has reported strong changes in local ancestry

23 in the genome of the Fula population from west Africa; the region overlapping the lactase 
1 persistence trait (LCT/MCMO) exhibits the highest proportion of Eurasian ancestry, while DARC,

2 where the Duffy null allele confers almost complete resistance to vivax malaria, exhibits the

3 highest proportion of African ancestry [81]. That adaptation can be accelerated by gene flow is

4 also supported by studies of African-descent, admixed populations of Madagascar and Pakistan,

5 where the Duffy null allele is, again, observed at higher frequencies than expected [82-84].

\section{Conclusions and perspectives}

8 Human evolutionary genomics in central Africa has contributed new knowledge of the history

9 and evolution of human groups inhabiting this ecologically unique region. Deep population

10 divergence between populations with historically distinct subsistence strategies, as well as

11 compelling signatures of local adaptation, suggest an early prehistory of central Africa

12 characterized by isolation between populations relying on different ecosystems. Conversely, the

13 Holocene witnessed the geographical expansion of demographically-successful, sedentary Bantu-

14 speaking peoples, resulting ultimately in asymmetric and male-biased admixture with several

15 groups of rainforest hunter-gatherers.

17 Despite these new insights, important aspects of the evolutionary past of central Africans remain

18 unclear, because of inherent limitations of modern population genomics and the scarcity of high-

19 quality genomic data for both modern and ancient human DNA. Uncertainties in the geographic

20 distribution of ancestors of present-day populations and in mutation rates impede the

21 interpretation of the demographic models fitted on the available genetic data [85]. The overall

22 genetic diversity of central Africans remains to be fully characterized, as the geographic

23 distribution of sampled populations is still fragmented, particularly in the Demographic Republic 
1 of Congo where several hunter-gatherer groups live, such as the Twa and the Cwa [1] (Figure 2).

2 The extreme scarcity of human fossils and the low preservation of ancient DNA in these regions

3 also hamper ancient genomics, yet this field is essential to confirm that archaic admixture with

4 ancient hominins did occur in Africa, and if so, to determine which modern populations were

5 mostly introgressed.

6

7 Finally, the contrasted demographic histories and ecologies of central African populations are

8 expected to impact their present-day phenotypic diversity, both benign and disease-related. While

9 compelling evidence support that a number of distinctive traits of rainforest hunter-gatherers and

10 farmers are adaptive, the genetic architecture of such traits, as well as that of diseases endemic of

11 this region, is yet to be determined. Future studies combining rich phenotype data with innovative

12 methodological tools to detect the footprints of polygenic selection and adaptive introgression

13 will provide invaluable insights into the determinants of human biological diversity. 


\section{BOX 1 - The genetic legacy of the Transatlantic Slave Trade}

2

3 Millions of individuals from western and central Africa were forcibly brought to the Americas by

4 slave traders from the $16^{\text {th }}$ to the $19^{\text {th }}$ centuries. Subsequent admixture between the descendants

5 of slaves and European- or Native-American-descent Americans impacted greatly the genetic

6 landscape of the New World. Contemporary American populations of African descent show

7 considerable variation in African ancestry proportions, ranging from $<5 \%$ in Puerto Ricans to

8 more than $95 \%$ in the Noir Marron from north-eastern South America [86-91]. Within North

9 America, innovative approaches modelling ancestry and recent relatedness estimated that

10 admixture occurred in the first half of the $19^{\text {th }}$ century mainly in the South, followed by ancestry-

11 biased migration towards the North [90].

12

13 Although rich historical records documented slave embarkations from different coastal regions of

14 western and central Africa [92], they could not inform the precise geographical origins of

15 African-descent Americans. These origins were recently revealed by genetic surveys that

16 estimated the relative genetic contribution of western and central African populations to African-

17 Americans [37,91], highlighting Angola as an important source of slaves in both South and North

18 America [93].

19

20 Leveraging the rich genealogical and genetic records of Iceland, a seminal study reconstructed

21 the African genome of Hans Jonatan, an Icelandic immigrant born in the Caribbean in 1784 to an

22 enslaved African mother and European father, from the genomes of 182 of his descendants in

23 Iceland, and inferred his mother originated from western central Africa [94]. 


\section{Conflict of interest statement}

2 Nothing declared.

3

\section{Acknowledgements}

5 We acknowledge funding from the Institut Pasteur, the Centre National de la Recherche

6 Scientifique (CNRS), the Histoire du Génome des Populations Humaines Gabonaises project

7 (Institut Pasteur/Republic of Gabon), and the Agence Nationale de la Recherche (ANR) grant

8 AGRHUM (ANR-14-CE02-0003-01). 


\section{References and recommended reading}

*of special interest

**of outstanding interest

1. Bahuchet S: Changing language, remaining pygmy. Hum Biol 2012, 84:11-43.

2. Hewlett BS: Cultural diversity among African pygmies. In Cultural Diversity Among Twentieth-Century Foragers. Edited by Kent S: Cambridge University Press; 1996.

3. Phillipson DW: African Archaeology. Cambridge: Cambridge University Press; 2005.

4. Hewlett BS: Hunter-gatherers of the Congo Basin: cultures, histories and biology of African Pygmies. New Jersey: Transaction Publishers; 2014.

5. Ohenjo N, Willis R, Jackson D, Nettleton C, Good K, Mugarura B: Health of Indigenous people in Africa. Lancet 2006, 367:1937-1946.

6. Verdu P: African Pygmies. Curr Biol 2016, 26:R12-14.

7. Perry GH, Dominy NJ: Evolution of the human pygmy phenotype. Trends Ecol Evol 2009, 24:218-225.

8. Cavalli-Sforza LL: African Pygmies. Edited by Cavalli-Sforza LL. New-York: Academic Press; 1986.

9. Bostoen K, Clist B, Doumenge C, Grollemund R, Hombert JM, Koni Muluwa J, Maley J: Middle to Late Holocene Paleoclimatic Change and the Early Bantu Expansion in the Rain Forests of Western Central Africa. Curr Anthropol 2015, 56:354-384.

10. Vansina J: Western Bantu expansion. J Afr Hist 1984, 25:129-145.

11. Mellars P: Why did modern human populations disperse from Africa ca. 60,000 years ago? A new model. Proc Natl Acad Sci U S A 2006, 103:9381-9386.

12. Mercader J: Forest people: The role of African rainforests in human evolution and dispersal. Evol Anthropol 2002, 11:117-124.

13. Crevecoeur I, Brooks A, Ribot I, Cornelissen E, Semal P: Late Stone Age human remains from Ishango (Democratic Republic of Congo): New insights on Late Pleistocene modern human diversity in Africa. J Hum Evol 2016, 96:35-57.

*14. Hsieh P, Veeramah KR, Lachance J, Tishkoff SA, Wall JD, Hammer MF, Gutenkunst RN: Whole-genome sequence analyses of Western Central African Pygmy hunter-gatherers reveal a complex demographic history and identify candidate genes under positive natural selection. Genome Res 2016, 26:279-290.

Throrough study of the demographic past and history of adaptation of rainforest hunter-gatherers, based on whole-genome sequences. Simulation-based genomic scans for evidence of selective sweeps and polygenic selection identified candidate genes involved in short stature, bone synthesis, muscle development, and immune responses.

*15. Lopez M, Kousathanas A, Quach H, Harmant C, Mouguiama-Daouda P, Hombert JM, Froment A, Perry GH, Barreiro LB, Verdu P, et al.: The demographic history and mutational load of African hunter-gatherers and farmers. Nat Ecol Evol 2018, 2:721730 . 
Integrates simulations with empirical data to assess the temporal trajectories of mutational load in central African hunter-gatherers and farmers. Despite their contrasting demographic pasts, both groups present today similar loads under additive and recessive models of dominance, owing to various demographic events that have hampered hunter-gatherers to accumulate recessive load.

16. Lipson M, Loh PR, Sankararaman S, Patterson N, Berger B, Reich D: Calibrating the Human Mutation Rate via Ancestral Recombination Density in Diploid Genomes. PLoS Genet 2015, 11:e1005550.

17. Fenner JN: Cross-cultural estimation of the human generation interval for use in genetics-based population divergence studies. Am J Phys Anthropol 2005, 128:415-423.

18. Patin E, Laval G, Barreiro LB, Salas A, Semino O, Santachiara-Benerecetti S, Kidd KK, Kidd JR, Van der Veen L, Hombert JM, et al.: Inferring the demographic history of African farmers and pygmy hunter-gatherers using a multilocus resequencing data set. PLoS Genet 2009, 5:e1000448.

19. Veeramah KR, Wegmann D, Woerner A, Mendez FL, Watkins JC, Destro-Bisol G, Soodyall H, Louie L, Hammer MF: An early divergence of KhoeSan ancestors from those of other modern humans is supported by an $\mathrm{ABC}$-based analysis of autosomal resequencing data. Mol Biol Evol 2012, 29:617-630.

20. Green RE, Krause J, Briggs AW, Maricic T, Stenzel U, Kircher M, Patterson N, Li H, Zhai W, Fritz MH, et al.: A draft sequence of the Neandertal genome. Science 2010, 328:710722.

21. Prufer K, Racimo F, Patterson N, Jay F, Sankararaman S, Sawyer S, Heinze A, Renaud G, Sudmant PH, de Filippo C, et al.: The complete genome sequence of a Neanderthal from the Altai Mountains. Nature 2014, 505:43-49.

22. Prufer K, de Filippo C, Grote S, Mafessoni F, Korlevic P, Hajdinjak M, Vernot B, Skov L, Hsieh P, Peyregne $S$, et al.: A high-coverage Neandertal genome from Vindija Cave in Croatia. Science 2017, 358:655-658.

23. Reich D, Green RE, Kircher M, Krause J, Patterson N, Durand EY, Viola B, Briggs AW, Stenzel U, Johnson PL, et al.: Genetic history of an archaic hominin group from Denisova Cave in Siberia. Nature 2010, 468:1053-1060.

24. Reich D, Patterson N, Kircher M, Delfin F, Nandineni MR, Pugach I, Ko AM, Ko YC, Jinam TA, Phipps ME, et al.: Denisova admixture and the first modern human dispersals into Southeast Asia and Oceania. Am J Hum Genet 2011, 89:516-528.

25. Vernot B, Tucci S, Kelso J, Schraiber JG, Wolf AB, Gittelman RM, Dannemann M, Grote S, McCoy RC, Norton H, et al.: Excavating Neandertal and Denisovan DNA from the genomes of Melanesian individuals. Science 2016, 352:235-239.

26. Rightmire GP: Out of Africa: modern human origins special feature: middle and later Pleistocene hominins in Africa and Southwest Asia. Proc Natl Acad Sci U S A 2009, 106: $16046-16050$.

27. Hammer MF, Woerner AE, Mendez FL, Watkins JC, Wall JD: Genetic evidence for archaic admixture in Africa. Proc Natl Acad Sci U S A 2011, 108:15123-15128.

28. Hsieh P, Woerner AE, Wall JD, Lachance J, Tishkoff SA, Gutenkunst RN, Hammer MF: Model-based analyses of whole-genome data reveal a complex evolutionary history involving archaic introgression in Central African Pygmies. Genome Res 2016, 26:291300 .

29. Lachance J, Vernot B, Elbers CC, Ferwerda B, Froment A, Bodo JM, Lema G, Fu W, Nyambo TB, Rebbeck TR, et al.: Evolutionary history and adaptation from high- 
coverage whole-genome sequences of diverse African hunter-gatherers. Cell 2012, 150:457-469.

30. Racimo F, Sankararaman S, Nielsen R, Huerta-Sanchez E: Evidence for archaic adaptive introgression in humans. Nat Rev Genet 2015, 16:359-371.

31. Maley J, Doumenge C, Giresse P, Mahé G, Philippon N, Hubau W, Lokonda MO, Tshibamba JM, Chepstow-Lusty A: Late Holocene forest contraction and fragmentation in central Africa. Quaternary Research 2017, 89:43-59.

32. Bayon G, Dennielou B, Etoubleau J, Ponzevera E, Toucanne S, Bermell S: Intensifying weathering and land use in Iron Age Central Africa. Science 2012, 335:1219-1222.

33. Holden CJ: Bantu language trees reflect the spread of farming across sub-Saharan Africa: a maximum-parsimony analysis. Proc Biol Sci 2002, 269:793-799.

34. Grollemund R, Branford S, Bostoen K, Meade A, Venditti C, Pagel M: Bantu expansion shows that habitat alters the route and pace of human dispersals. Proc Natl Acad Sci U S A 2015, 112:13296-13301.

35. Tishkoff SA, Reed FA, Friedlaender FR, Ehret C, Ranciaro A, Froment A, Hirbo JB, Awomoyi AA, Bodo JM, Doumbo O, et al.: The Genetic Structure and History of Africans and African Americans. Science 2009, 324:1035-1044.

36. Gurdasani D, Carstensen T, Tekola-Ayele F, Pagani L, Tachmazidou I, Hatzikotoulas K, Karthikeyan S, Iles L, Pollard MO, Choudhury A, et al.: The African Genome Variation Project shapes medical genetics in Africa. Nature 2015, 517:327-332.

*37. Patin E, Lopez M, Grollemund R, Verdu P, Harmant C, Quach H, Laval G, Perry GH, Barreiro LB, Froment A, et al.: Dispersals and genetic adaptation of Bantu-speaking populations in Africa and North America. Science 2017, 356:543-546.

Genomic data from 1,318 individuals from different African regions provide proof-of-concept that admixture between human populations - Bantu-speaking farmers with local populations of hunter-gatherers and pastoralists — represents a rapid means to acquire new adaptive variation, with examples related to immune responses and metabolism.

38. Busby GB, Band G, Si Le Q, Jallow M, Bougama E, Mangano VD, Amenga-Etego LN, Enimil A, Apinjoh T, Ndila CM, et al.: Admixture into and within sub-Saharan Africa. Elife 2016, 5:e15266.

39. de Filippo C, Bostoen K, Stoneking M, Pakendorf B: Bringing together linguistic and genetic evidence to test the Bantu expansion. Proc Biol Sci 2012, 279:3256-3263.

40. Aimé C, Laval G, Patin E, Verdu P, Ségurel L, Chaix R, Hegay T, Quintana-Murci L, Heyer $\mathrm{E}$, Austerlitz F: Human genetic data reveal contrasting demographic patterns between sedentary and nomadic populations that predate the emergence of farming. Mol Biol Evol 2013, 30:2629-2644.

41. Patin E, Siddle KJ, Laval G, Quach H, Harmant C, Becker N, Froment A, Regnault B, Lemee L, Gravel S, et al.: The impact of agricultural emergence on the genetic history of African rainforest hunter-gatherers and agriculturalists. Nat Commun 2014, 5:3163.

42. Quintana-Murci L, Quach H, Harmant C, Luca F, Massonnet B, Patin E, Sica L, MouguiamaDaouda $\mathrm{P}$, Comas D, Tzur S, et al.: Maternal traces of deep common ancestry and asymmetric gene flow between Pygmy hunter-gatherers and Bantu-speaking farmers. Proc Natl Acad Sci U S A 2008, 105:1596-1601. 
43. Verdu P, Austerlitz F, Estoup A, Vitalis R, Georges M, Thery S, Froment A, Le Bomin S, Gessain A, Hombert JM, et al.: Origins and genetic diversity of pygmy hunter-gatherers from Western Central Africa. Curr Biol 2009, 19:312-318.

44. Verdu P, Becker NS, Froment A, Georges M, Grugni V, Quintana-Murci L, Hombert JM, Van der Veen L, Le Bomin S, Bahuchet S, et al.: Sociocultural behavior, sex-biased admixture, and effective population sizes in Central African Pygmies and non-Pygmies. Mol Biol Evol 2013, 30:918-937.

45. Jarvis JP, Scheinfeldt LB, Soi S, Lambert C, Omberg L, Ferwerda B, Froment A, Bodo JM, Beggs W, Hoffman G, et al.: Patterns of ancestry, signatures of natural selection, and genetic association with stature in Western African pygmies. PLoS Genet 2012, 8:e1002641.

**46. Mallick S, Li H, Lipson M, Mathieson I, Gymrek M, Racimo F, Zhao M, Chennagiri N, Nordenfelt S, Tandon A, et al.: The Simons Genome Diversity Project: 300 genomes from 142 diverse populations. Nature 2016, 538:201-206.

**47. Malaspinas AS, Westaway MC, Muller C, Sousa VC, Lao O, Alves I, Bergstrom A, Athanasiadis G, Cheng JY, Crawford JE, et al.: A genomic history of Aboriginal Australia. Nature 2016, 538:207-214.

These two studies [46,47] report remarkable, novel datasets of whole genome sequences from different populations worldwide. They address questions of major importance in human evolution, including the genetic structure of understudied populations such as Aboriginal Australians and western Melanesians, the timing of past population divergence and early dispersals out of Africa, and the history of archaic admixture of modern humans.

48. Tennessen JA, Bigham AW, O'Connor TD, Fu W, Kenny EE, Gravel S, McGee S, Do R, Liu $\mathrm{X}$, Jun $\mathrm{G}$, et al.: Evolution and functional impact of rare coding variation from deep sequencing of human exomes. Science 2012, 337:64-69.

49. Agarwala V, Flannick J, Sunyaev S, Go TDC, Altshuler D: Evaluating empirical bounds on complex disease genetic architecture. Nat Genet 2013, 45:1418-1427.

50. Maher MC, Uricchio LH, Torgerson DG, Hernandez RD: Population genetics of rare variants and complex diseases. Hum Hered 2012, 74:118-128.

51. Lohmueller KE: The distribution of deleterious genetic variation in human populations. Curr Opin Genet Dev 2014, 29:139-146.

52. Simons YB, Sella G: The impact of recent population history on the deleterious mutation load in humans and close evolutionary relatives. Curr Opin Genet Dev 2016, 41:150-158.

53. Henn BM, Botigue LR, Bustamante CD, Clark AG, Gravel S: Estimating the mutation load in human genomes. Nat Rev Genet 2015, 16:333-343.

54. Becker NS, Verdu P, Froment A, Le Bomin S, Pagezy H, Bahuchet S, Heyer E: Indirect evidence for the genetic determination of short stature in African Pygmies. Am J Phys Anthropol 2011, 145:390-401.

55. Perry GH, Foll M, Grenier JC, Patin E, Nedelec Y, Pacis A, Barakatt M, Gravel S, Zhou X, Nsobya SL, et al.: Adaptive, convergent origins of the pygmy phenotype in African rainforest hunter-gatherers. Proc Natl Acad Sci U S A 2014, 111:E3596-3603.

56. Diamond JM: Anthropology. Why are pygmies small? Nature 1991, 354:111-112.

57. Migliano AB, Vinicius L, Lahr MM: Life history trade-offs explain the evolution of human pygmies. Proc Natl Acad Sci U S A 2007, 104:20216-20219. 
58. Perry GH, Verdu P: Genomic perspectives on the history and evolutionary ecology of tropical rainforest occupation by humans. Quaternary International 2017, 448:150-157.

59. Mendizabal I, Marigorta UM, Lao O, Comas D: Adaptive evolution of loci covarying with the human African Pygmy phenotype. Hum Genet 2012, 131:1305-1317.

60. Amorim CE, Daub JT, Salzano FM, Foll M, Excoffier L: Detection of convergent genomewide signals of adaptation to tropical forests in humans. PLoS One 2015, 10:e121557.

61. Migliano AB, Romero IG, Metspalu M, Leavesley M, Pagani L, Antao T, Huang DW, Sherman BT, Siddle K, Scholes C, et al.: Evolution of the pygmy phenotype: evidence of positive selection fro genome-wide scans in African, Asian, and Melanesian pygmies. Hum Biol 2013, 85:251-284.

62. Lopez Herraez D, Bauchet M, Tang K, Theunert C, Pugach I, Li J, Nandineni MR, Gross A, Scholz M, Stoneking M: Genetic variation and recent positive selection in worldwide human populations: evidence from nearly 1 million SNPs. PLoS One 2009, 4:e7888.

*63. Rozzi FV, Koudou Y, Froment A, Le Bouc Y, Botton J: Growth pattern from birth to adulthood in African pygmies of known age. Nat Commun 2015, 6:7672.

This in-depth longitudinal study of height and weight in hundreds of African rainforest huntergatherers suggests that small adult body size of western and eastern groups was achieved through different evolutionary trajectories, with the pygmy phenotype in western central Africa resulting from a slow growth during infancy

64. Pritchard JK, Pickrell JK, Coop G: The genetics of human adaptation: hard sweeps, soft sweeps, and polygenic adaptation. Curr Biol 2010, 20:R208-215.

65. Barreiro LB, Quintana-Murci L: From evolutionary genetics to human immunology: how selection shapes host defence genes. Nat Rev Genet 2010, 11:17-30.

*66. Fan S, Hansen ME, Lo Y, Tishkoff SA: Going global by adapting local: A review of recent human adaptation. Science 2016, 354:54-59.

Comprehensive review of how modern human popoulations have biologically adapted to varying selective pressures, with examples of local adaptations related to dairy consumption, artic and tropical rainforest environments, hypoxia, ultraviolet exposure and infectious agents.

67. Kwiatkowski DP: How malaria has affected the human genome and what human genetics can teach us about malaria. Am J Hum Genet 2005, 77:171-192.

68. Sabeti PC, Reich DE, Higgins JM, Levine HZ, Richter DJ, Schaffner SF, Gabriel SB, Platko JV, Patterson NJ, McDonald GJ, et al.: Detecting recent positive selection in the human genome from haplotype structure. Nature 2002, 419:832-837.

69. Hamblin MT, Di Rienzo A: Detection of the signature of natural selection in humans: evidence from the Duffy blood group locus. Am J Hum Genet 2000, 66:1669-1679.

70. Allison AC: Protection afforded by sickle-cell trait against subtertian malareal infection. Br Med J 1954, 1:290-294.

71. Ruwende C, Khoo SC, Snow RW, Yates SN, Kwiatkowski D, Gupta S, Warn P, Allsopp CE, Gilbert SC, Peschu N, et al.: Natural selection of hemi- and heterozygotes for G6PD deficiency in Africa by resistance to severe malaria. Nature 1995, 376:246-249.

72. Fry AE, Ghansa A, Small KS, Palma A, Auburn S, Diakite M, Green A, Campino S, Teo YY, Clark TG, et al.: Positive selection of a CD36 nonsense variant in sub-Saharan Africa, but no association with severe malaria phenotypes. Hum Mol Genet 2009, 18:2683-2692. 
73. Deschamps M, Laval G, Fagny M, Itan Y, Abel L, Casanova JL, Patin E, Quintana-Murci L: Genomic Signatures of Selective Pressures and Introgression from Archaic Hominins at Human Innate Immunity Genes. Am J Hum Genet 2016, 98:5-21.

74. Barreiro LB, Laval G, Quach H, Patin E, Quintana-Murci L: Natural selection has driven population differentiation in modern humans. Nat Genet 2008, 40:340-345.

75. Ko WY, Rajan P, Gomez F, Scheinfeldt L, An P, Winkler CA, Froment A, Nyambo TB, Omar SA, Wambebe $\mathrm{C}$, et al.: Identifying Darwinian selection acting on different human APOL1 variants among diverse African populations. Am J Hum Genet 2013, 93:54-66.

76. Andersen KG, Shylakhter I, Tabrizi S, Grossman SR, Happi CT, Sabeti PC: Genome-wide scans provide evidence for positive selection of genes implicated in Lassa fever. Philos Trans R Soc Lond B Biol Sci 2012, 367:868-877.

77. Grossman SR, Andersen KG, Shlyakhter I, Tabrizi S, Winnicki S, Yen A, Park DJ, Griesemer D, Karlsson EK, Wong SH, et al.: Identifying recent adaptations in large-scale genomic data. Cell 2013, 152:703-713.

78. Vattathil S, Akey JM: Small Amounts of Archaic Admixture Provide Big Insights into Human History. Cell 2015, 163:281-284.

79. Kelso J, Prufer K: Ancient humans and the origin of modern humans. Curr Opin Genet Dev 2014, 29:133-138.

80. Jeong C, Alkorta-Aranburu G, Basnyat B, Neupane M, Witonsky DB, Pritchard JK, Beall CM, Di Rienzo A: Admixture facilitates genetic adaptations to high altitude in Tibet. Nat Communs 2014, 5:3281.

**81. Busby G, Christ R, Band G, Leffler EM, Le QS, Rockett K, Kwiatkowski D, Spencer C: Inferring adaptive gene-flow in recent African history. bioRxiv 2017, doi: https://doi.org/10.1101/205252

Detailed study of how gene flow in African populations, occurring within the last 4,000 years, has driven local adaptation. Applying a novel method to detect strong deviations in local ancestry, this study identifies adaptive functions, including lactase persistence in adulthood and resistance to malaria, acquired by the western African Fulani via gene flow.

82. Laso-Jadart R, Harmant C, Quach H, Zidane N, Tyler-Smith C, Mehdi Q, Ayub Q, QuintanaMurci L, Patin E: The Genetic Legacy of the Indian Ocean Slave Trade: Recent Admixture and Post-admixture Selection in the Makranis of Pakistan. Am J Hum Genet 2017, 101:977-984.

*83. Pierron D, Heiske M, Razafindrazaka H, Pereda-Loth V, Sanchez J, Alva O, Arachiche A, Boland A, Olaso R, Deleuze JF, et al.: Strong selection during the last millennium for African ancestry in the admixed population of Madagascar. Nat Commun 2018, 9:932.

Analysis of local ancestry and positive selection in the admixed Malagasy, who offer an excellent opportunity to explore the adaptive nature of relatively ancient admixture, occurring $\sim 700$ years ago, between Asian and African populations.

84. Hodgson JA, Mulligan CJ, Al-Meeri A, Raaum RL: Early back-to-Africa migration into the Horn of Africa. PLoS Genet 2014, 10:e1004393.

85. Nielsen R, Akey JM, Jakobsson M, Pritchard JK, Tishkoff S, Willerslev E: Tracing the peopling of the world through genomics. Nature 2017, 541:302-310. 
86. Montinaro F, Busby GB, Pascali VL, Myers S, Hellenthal G, Capelli C: Unravelling the hidden ancestry of American admixed populations. Nat Commun 2015, 6:6596.

87. Bryc K, Durand EY, Macpherson JM, Reich D, Mountain JL: The genetic ancestry of African Americans, Latinos, and European Americans across the United States. Am J Hum Genet 2015, 96:37-53.

88. Moreno-Estrada A, Gravel S, Zakharia F, McCauley JL, Byrnes JK, Gignoux CR, Ortiz-Tello PA, Martinez RJ, Hedges DJ, Morris RW, et al.: Reconstructing the population genetic history of the Caribbean. PLoS Genet 2013, 9:e1003925.

89. Mathias RA, Taub MA, Gignoux CR, Fu W, Musharoff S, O'Connor TD, Vergara C, Torgerson DG, Pino-Yanes M, Shringarpure SS, et al.: A continuum of admixture in the Western Hemisphere revealed by the African Diaspora genome. Nat Commun 2016, 7:12522.

**90. Baharian S, Barakatt M, Gignoux CR, Shringarpure S, Errington J, Blot WJ, Bustamante CD, Kenny EE, Williams SM, Aldrich MC, et al.: The Great Migration and AfricanAmerican Genomic Diversity. PLoS Genet 2016, 12:e1006059.

Combining genomic data from 3,726 African-Americans across the US with refined demographic modeling of ancestry and relatedness, this study explores the timing and geographic location of admixture between their ancestors, and shows that their history of ancestry-biased migration has affected regional differences in ancestry among African-Americans.

91. Fortes-Lima C, Gessain A, Ruiz-Linares A, Bortolini MC, Migot-Nabias F, Bellis G, Moreno-Mayar JV, Restrepo BN, Rojas W, Avendano-Tamayo E, et al.: Genome-wide Ancestry and Demographic History of African-Descendant Maroon Communities from French Guiana and Suriname. Am J Hum Genet 2017, 101:725-736.

92. Eltis D, Richardson D: Atlas of the Transatlantic Slave Trade: Yale University Press; 2010.

93. Domingues da Silva DB: The Atlantic Slave Trade from Angola: A Port-by-Port Estimate of Slaves Embarked, 1701-1867. Int J Afr Hist Stud 2013, 46:105-122.

94. Jagadeesan A, Gunnarsdottir ED, Ebenesersdottir SS, Guethmundsdottir VB, Thordardottir EL, Einarsdottir MS, Jonsson H, Dugoujon JM, Fortes-Lima C, Migot-Nabias F, et al.: Reconstructing an African haploid genome from the 18th century. Nat Genet 2018, 50:199-205.

95. Hay SI, Guerra CA, Gething PW, Patil AP, Tatem AJ, Noor AM, Kabaria CW, Manh BH, Elyazar IR, Brooker S, et al.: A world malaria map: Plasmodium falciparum endemicity in 2007. PLoS Med 2009, 6:e1000048. 


\section{Figures}

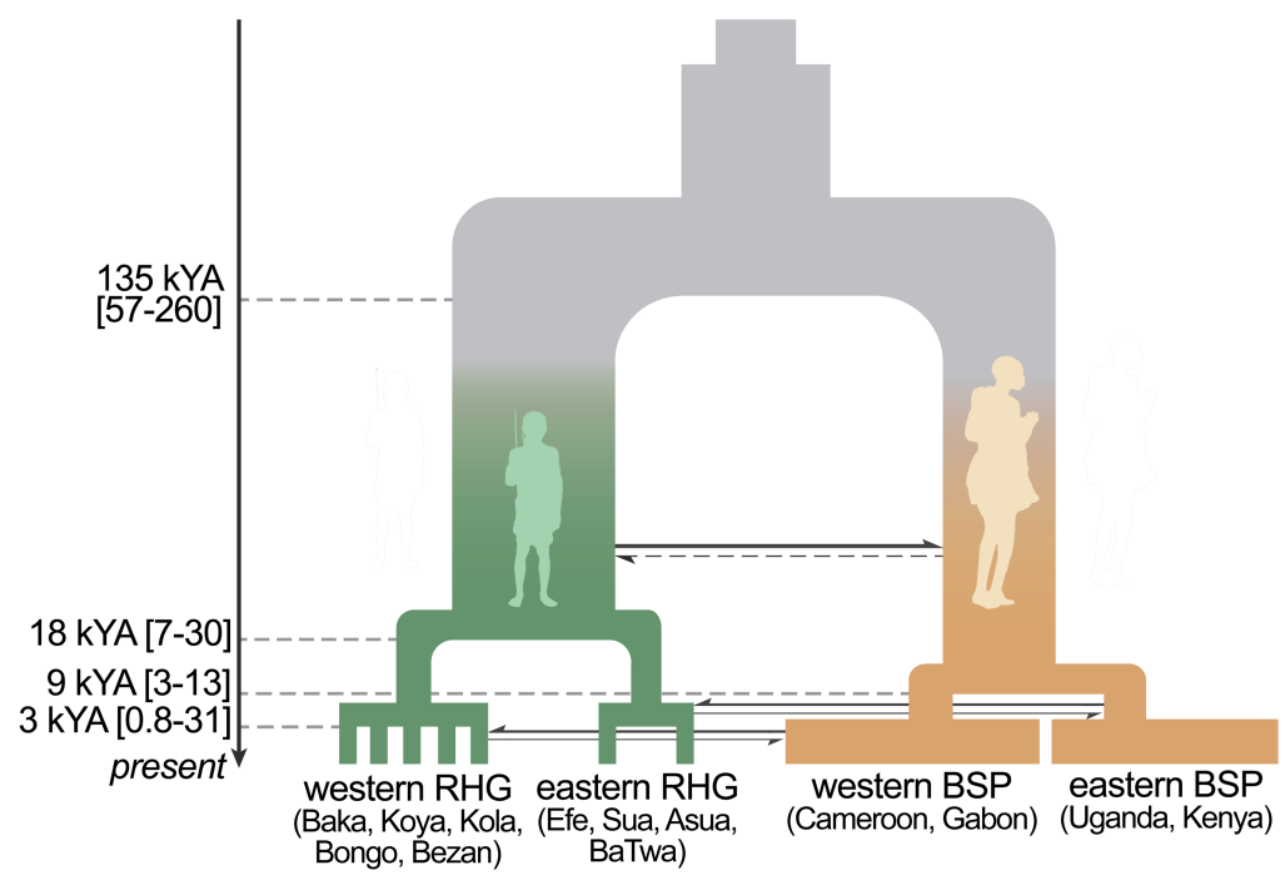

Figure 1. A general demographic model of rainforest hunter-gatherer and farmer

populations. This model recapitulates estimations of the demographic history of rainforest hunter-gatherers (RHG) and neighbouring Bantu-speaking farmer populations (BSP) of central Africa $[15,41,43]$. Times are given in thousands of years from present (kYA). Inferred changes in effective population size are shown by changes in branch width, and gene flow by arrows. 


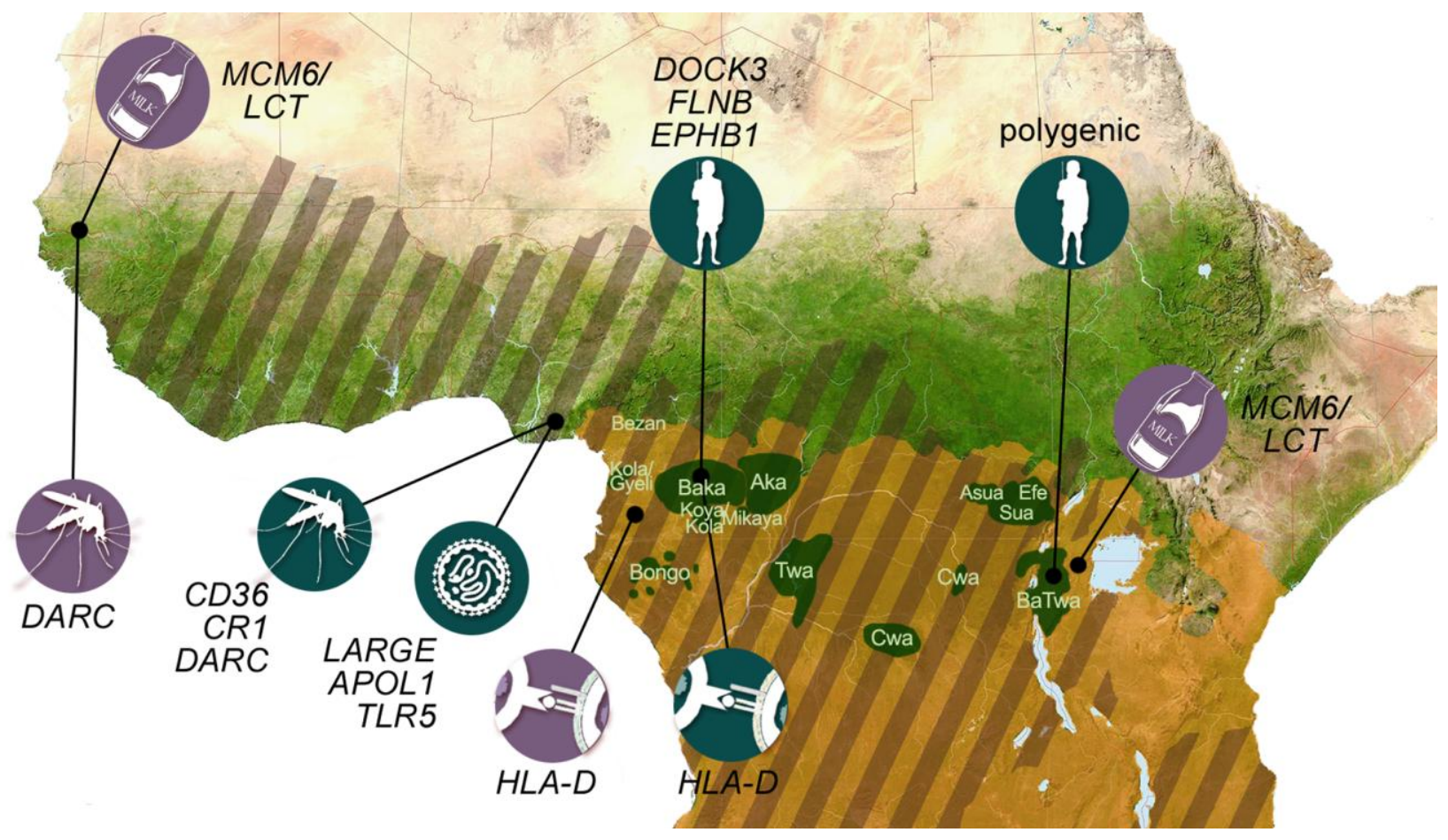

Figure 2. A map of human local adaptations in central Africa. Blue circles indicate case examples of candidate local adaptations and corresponding positively-selected genes in western/central Africa. Violet circles indicate candidate cases of adaptive admixture, when adaptive variation was acquired through admixture or gene flow. The orange area shows where Bantu languages are spoken today (adapted from [3]). Dark green areas indicate the geographic areas that the different RHG groups occupy (adapted from [1]). The maroon hatched areas indicate predicted areas of high Plasmodium falciparum malaria endemicity [95]. 